\title{
講 習会記録
}

金属塗装法講習会

時 昭和 32 年 5 月 20 日 24 日

所 生命保険協会講堂

第 1 日 第 1 講，塗装技術者のための金属材料講座

$\begin{array}{lllll}669-181 . & \text { a 板材の表面 } & \text { 麻田 宏(東京大学理工学研究所) } \\ 669,13-181 . & \text { b } & \text { 鋳物の表面 } & \text { 堀江 勇 (東京重機工業株式会社) }\end{array}$

檴 演 要 旨

\section{板材 の 表 面}

\section{I. 板材の製造中における表面変化}

板材の製造行程は，合金の種類，板の用途に従つて 相違するが，一般的には次の通りである。
麻

H

空

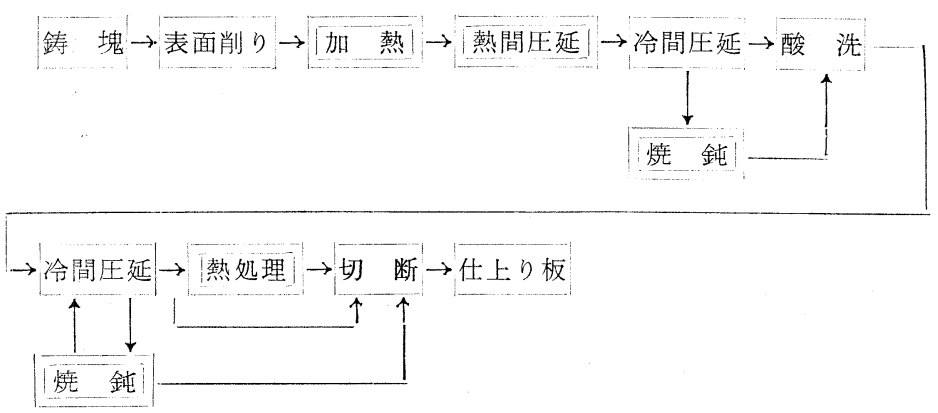

車, 自動車, 機械部品, 農機具等に使用される。帯は 長尺ものでループに扮いてあるものである。

（5）磨帯鋼自転車, 自動車, ケーブル鎧装用 で, 表面仕上を丁寧にしたもので ある。

(6) アルミニウム板器物, 建築等に使用される。冷間圧延の ままのものあるいは焼鈍したもの がある。

(7) アルミニウム合金板

車輛, 船舶, 建築, 航空機等に用 いられる。厚板は熱間圧延のまま のものがある。ただし，鋼板のご

2 重に囲まれた行程で, 表面に酸化を甚しく受ける。 最後の焼鈍では酸化を嫌う場合は中性瓦斯中で光輝烧 鈍を行う。また熱処理材は焼入焼戻を行ら。

\section{II. 各種板の性澌}

（1）厚鋼板 造船, 車輛, 橋梁, 建築に使用す る。これは熟間圧延のままであるから, 表面に酸化膜 (ミルスケール) がある。

（2）薄鋼板亜鉛鉄板，ドラム罐に使用する。 これは冷間圧延のままか,その後焼鈍した板である。 表面の酸化膜は厚くない。

（3）高級仕上鋼板自転車，車輛，高級家具等 で, 表面仕上を丁寧にしたものである。また深絞性も める。
（4）带 鋼 磨帯䨩, ガス管, 一般鋼管, 自転

とく厚い酸化膜はかぶっている。薄板は冷間圧延のも 第 1 表 板材の材質記号記号

\begin{tabular}{|c|c|c|}
\hline 記号 & 状 & 旧記号 \\
\hline$-F$ & 製造の类ま & $1 / 4 \mathrm{H} \approx \mathrm{H}_{12} \approx \mathrm{H}_{22}$ \\
\hline$-\mathrm{O}$ & 焼鈍ずみ & $1 / 2 \mathrm{H} \approx \mathrm{H}_{14} \approx \mathrm{H}_{24}$ \\
\hline$-\mathrm{H}$ & 加 工 硬 化 & $3 / 4 \mathrm{H} \approx \mathrm{H}_{16} \approx \mathrm{H}_{26}$ \\
\hline$-\mathrm{H}_{1}$ & 加 工 硬 化 & $\begin{array}{c}\mathrm{H} \approx \mathrm{H}_{18} \\
\text { 特硬 } \approx \mathrm{H}_{19}\end{array}$ \\
\hline$-\mathrm{H}_{2}$ & 加工硬化後, 部分的焼鈍 & Non \\
\hline$-\mathrm{H}_{3}$ & 加工硬化安定化したもの & 硬 \\
\hline$-W$ & 溶体化処理 & 化 \\
\hline$-\mathrm{T}_{3}$ & $\begin{array}{l}\text { 溶体処理後, 冷間加工せる } \\
\text { ○の }\end{array}$ & 一 \\
\hline$-\mathrm{T}_{4}$ & 溶体化処理（焼入） & 部 \\
\hline$-\mathrm{T}_{6}$ & 溶体化処理後, 人工時動 & $\begin{array}{l}\text { 䛈 } \\
\text { 針 }\end{array}$ \\
\hline
\end{tabular}


の，焼鈍状態，熱処理後矯正圧延したもがの等女る。 熱処理材の表面は相等に酸化された状態である。（第 1 表参照)

（8）アルミニウム合金合せ板防食を目的とし，ア ルミニウム合金板の上に，アルミニウムを板厚の $4 \%$ 位（片側）被せた板で，外皮と心材とは完全に合金し ている。多くは熱処理材である。

（9）銅板，真鍮板焼鈍に際して酸化消耗を少 くするようにしている。

（10）亜鉛鍍鋼板薄鋼板の上に防食を目的とし て，亜鉛のドブ漬けをし，(熔融メッキ），业鉛を被せ たものである。亜鉛と鉄との境界は合金となってい る。亜鉛の持つ耐食性と，覀鉛と鉄との電気化学的性 質による防食効果とが有効になる。板の表面は亜鉛の 凝固組織である。

（11）ブリキ 薄鋼板の上に防食を目的として， スズを愹融メッキ女るいは，電気メッキしたものであ る。スズの耐食性が有効であって, 電気化学的な効果 はない。

\section{III. 鉄 の 酸 化}

$560^{\circ} \mathrm{C}$ 以上では $\mathrm{Fe}|\mathrm{FeO}| \mathrm{Fe}_{3} \mathrm{O}_{4}\left|\mathrm{Fe}_{2} \mathrm{O}_{3}\right| \dot{\mathrm{O}}_{2}$ $\begin{array}{lllll}560^{\circ} \mathrm{C} \text { 以下では } & \mathrm{Fe} & \mathrm{Fe}_{3} \mathrm{O}_{4} & \mathrm{Fe}_{2} \mathrm{O}_{3} & \mathrm{O}_{2}\end{array}$ 以上のような酸化膜を生成する。

熱間圧延温度で, $800 \sim 1,000^{\circ} \mathrm{C}$ 位の時は 3 層の酸化 膜になる。 $1,100^{\circ} \mathrm{C}$ 以上では $\mathrm{Fe}_{2} \mathrm{O}_{4}$ はあまりできず, $\mathrm{Fe}_{3} \mathrm{O}_{4}$ の黑色酸化膜で被われる。(第 1 図参照)

第 1 図鉄々酸素の平衡図

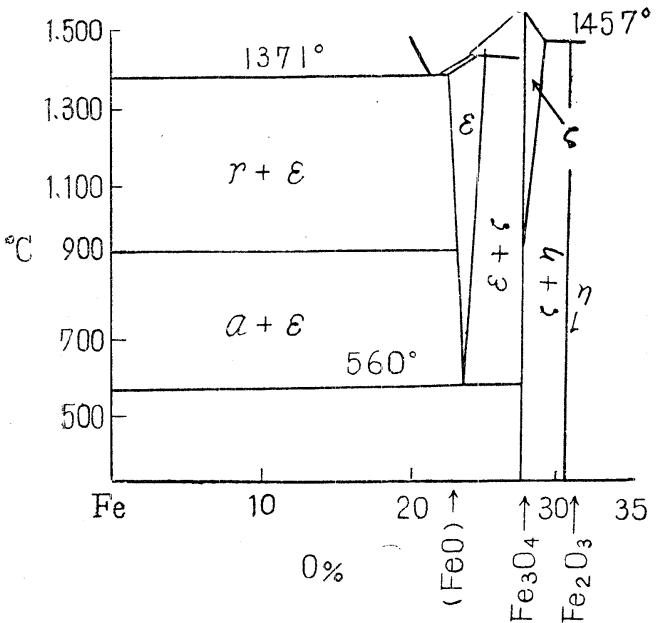

酸素は酸化鉄の膜を滲透するから，鉄の酸化は時間 之共に做物線的に增加する。

鉄が $350^{\circ} \mathrm{C}$ 位に加熱された時には青黒色の酸化膜が
第 2 図 時間一酸化量

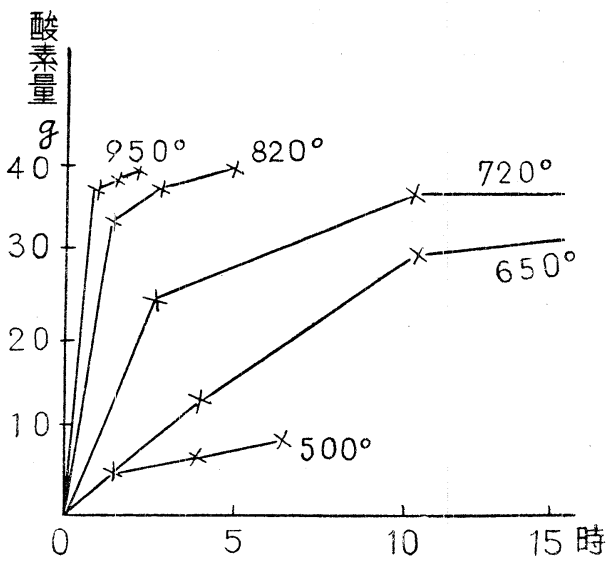

できる。温度の高低で色彩が変るが，テンパーカラと いっている。

第 3 図雾囲気と酸化

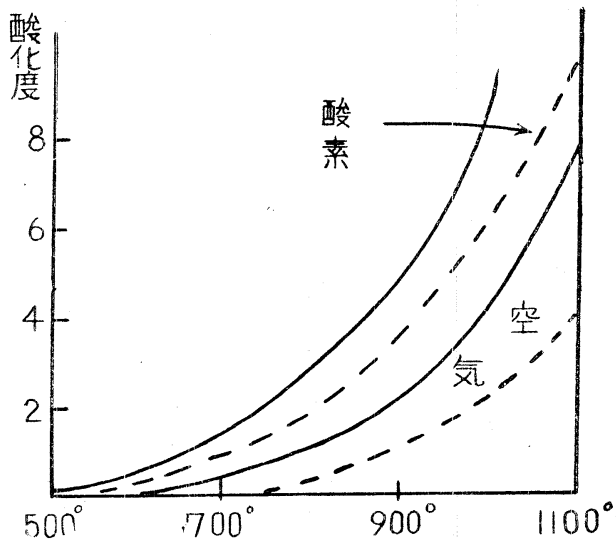

酸化と温度の関係は, $550^{\circ} \mathrm{C}$ 以上では急激な酸化が 起る。（第 2 図，第 3 図参照）

鋼を $650 \sim 900^{\circ} \mathrm{C}$ に熱し，これに水蒸気を吹きつけ ると， $\mathrm{Fe}_{3} \mathrm{O}_{4}$ の被膜ができて，この膜は相当に耐食性 がある。ミルスケールも同様の酸化膜であるが，一部 が，はげると基地の鉄との間に電気化学的な腐食を起 す。最近は船舶の外板は，サンドブラスト等を用い， ミルスケールを取除いて塗装している。

$\mathrm{Fe}_{2} \mathrm{O}_{3}$ は吸湿性であるから，水分を鋼面に供給して 腐食を促進させる。従って塗装に除しては除去すべき である。

\section{IV. アルミニウムの酸化}

アルミニウムの表面には，空気中で酸化アルミニウ ムの極くうすい膜ができる。この膜は強固であるから 酸素の滲透が少く，鉄のように酸化の進行は甚だしく 
第 4-1 図 粗度と塗料の密着

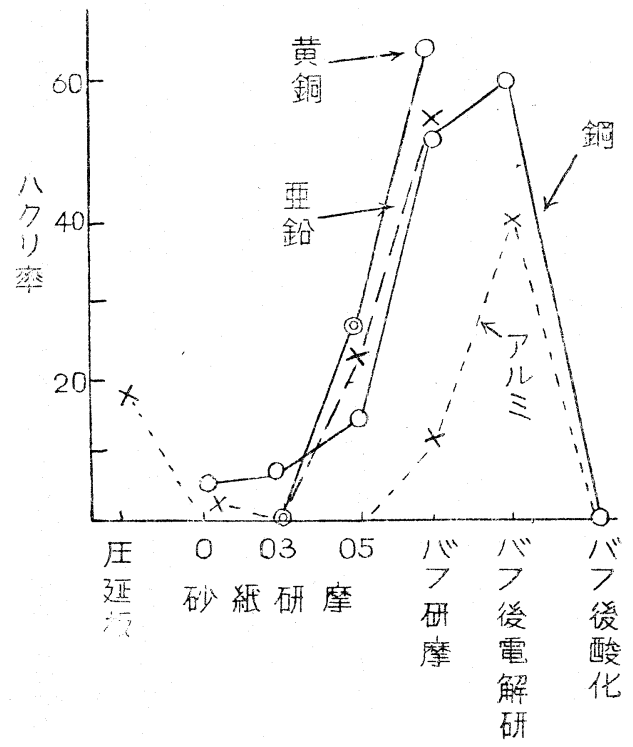

第 4-2 図 粗 度(鋼)

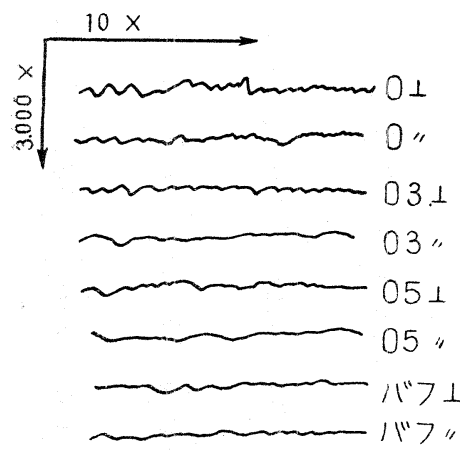

ない゚しかし， 高温で多れば かなり進行す る。

酸化アルミ ニウム強固 に基地と結合 して防食の役 を果している。

熱処理材,

焼鈍材等はこ の膜で被われ

ている。したがって耐食性のためには除去しないうが 良い。

陽極酸化で表面に厚い酸化膜をつくることができる

第 4-3 図 粗 度 (銅)

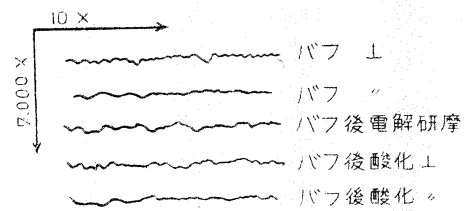

が，これは多孔質のもので岕って，染料の分子が法入 できる位である。これを蒸気処理すれば, 結晶質の膜 となり，耐食性が極めて良くなる。しかし，塗装下地 としては蒸気処理をしない方が良い。

\section{V. 酸化膜の存在と塗料の密着性}

バフで非常によく研摩した鉄やアルミニウムの面と これを加熱酸化（極く僅か）させた面とでは，後者の 方が遥かに塗料の密着性が良い。(第 4 図参照)

西鉛鋼板等も，風化した後に塗装する方が良いとい るれている。

\section{VI. 金属組織と㳂料の密着性}

一般飞使用されている鋼板は炭素を $0.3 \%$ 位含有 した崖素鋼である。これは炭素は極く少量（０.01\%以 下）が鉄の結晶中に固溶して， $\alpha$ 鉄となっているが， それ以外はセメンタイト $\left(\mathrm{Fe}_{3} \mathrm{C}\right)$ となって, 共析組織 ( $\alpha$ 鉄と $\mathrm{Fe}_{3} \mathrm{C}$ と極くこまかい混晶)中に入ってくる。 (第 5 図参照)

$\alpha$ 鉄の部分と $\mathrm{Fe}_{3} \mathrm{C}$ との部分では, 電気化学的な性 質も違らから，塗料の密着も違うであららが，どれぐ らい，相違するかは未だ研究されていない。

腐食は $\propto$ 鉄と $\mathrm{Fe}_{3} \mathrm{C}$ との間に激しく起るから $\mathrm{Fe}_{3} \mathrm{C}$ の多い鋼佂ど，サビ易い。

アルミニウム板も，純度が悪いものは， $\mathrm{FeAl}_{3}$ と $\mathrm{Si}$ とが，結晶粒界に出て，腐食され易くなる。なた，熱 処理合金では，金属間化合物の粒子が析出して，基地 との間で，腐食を促進させる。従って，他の結晶が現 われていないアルミニウム，なたは，アルミニウム合
第 5 図 C $0.3 \%$ 崖素鋼 顕微鏡組織

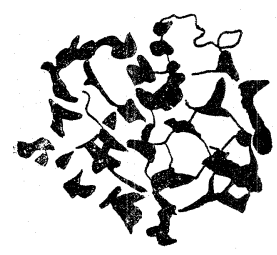

白: $\alpha$ 鉄

黑：パーライト $\left(\alpha+\mathrm{Fe}_{3} \mathrm{C}\right)$
第6 図各種な面の表示

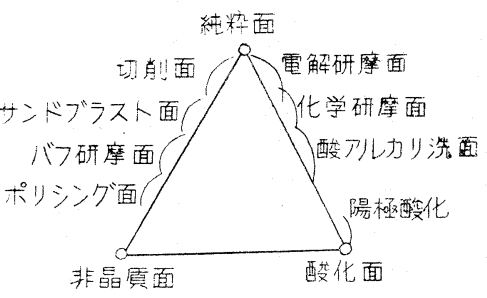

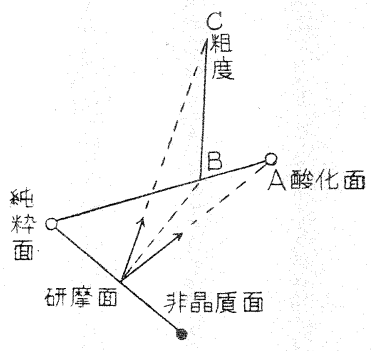


金の方が耐食性が良い。

\section{VII. 仕上面と塗料の密着性}

金属板の仕上面は，第 6 四から解るように，仕上前 の状態で異る。熱間圧延板，焼鈍板，熱処理板，は酸 化膜を相当厚く, 被っている。

冷間圧延板は，圧延用ロ一ルの面を転写してくるか
ら，ロールが鏡面であれば，鏡のような板となる。材 質的には歪んだ結晶となっている。先の極く表面は， 非結晶質の膜が存在する。

金属板を切削，研削した時には，その表面は，それ ぞれ違った状態である。

\section{鋳物 の 表 面}

東京重機工業(株) 堀江勇

\section{1. まえがき}

鋳物には一般に，鉄系統拈上び非鉄系統のものがあ るが，ミシンの場合には鉄系統が主であるので鋳鉄に 限ることにする。

鋼は鉄扔よび鉄と炭素の化合物 $\mathrm{Fe}_{3} \mathrm{C}$ の二相からな っているが，鋳鉄恃鉄と $\mathrm{Fe}_{3} \mathrm{C}$ との炭素の組合せにな ってあらわれ，特に炭素は種々なる形状をるつてあら われる極めて複雑な状態のるのである。

両者の製造過程を考光て見るに, 鋼の場合には, イ ンゴットに鋳込んだ後目的に応じて，線引きし，压延 し, 塗装用鋼板としては, 摩带鋼, 高級仕上鋼板とい った極めて平滑で，美麗な材料沉するとができる。 そ机対して鋳鉄の場合には，主として砂型に鋳込几 だそのままの状態のものが多く, 膚が荒くでこぼこの 他に巣孔といらやつかいなるのがあり, 乙か子塗装後 に掠ける仕上りは鋼板と同一の美麗さと耐久性が要求 される。

以上のごとく表面の状態の悪い鋳物の欠陥と，その 塗装上の処置について述べて見る。长の前に䏾物の概 念注き応述べるのが順序と思う。

\section{2. 鋳物の分類}

i) 鼠銈
ii) 日 銑
iii) 斑 銑

今日所謂鋳鉄として取报われるるのについて分類す ると第 1 表の通りになる。

\section{3. 鋳鉄に現われる組織}

鋼の場合と著しく異るものは黒鉛である。鋳鉄に黒 鉛が多量に現われていない場合には，その代りに $\mathrm{Fe}_{3} \mathrm{C}$ が多量に出現する。

素地の組織として鋼と同様汇次の夕のがある。

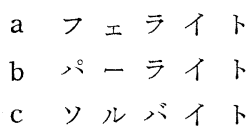

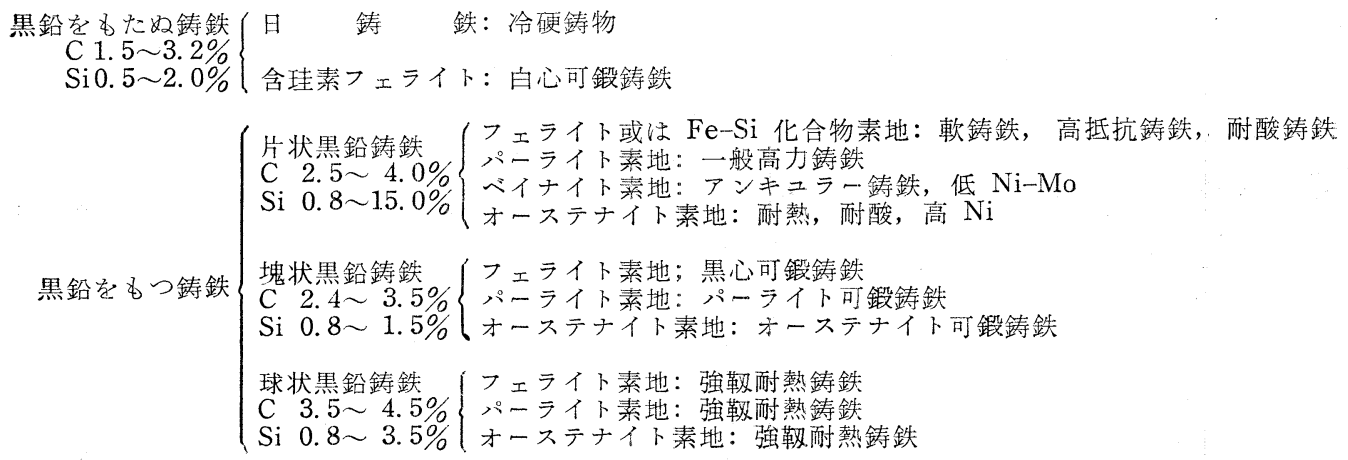

